Volume and Issues Obtainable at Center for Sustainability Research and Consultancy
Review of Politics and Public Policy in Emerging Economies
ISSN: 2708-3829 \& (E): 2708-356X
Volume 3: No. 1, June 2021
CSRC
Journal homepage: www.publishing.globalcsrc.org/rope

\title{
Implementation of Juvenile Justice System Act 2018: Prospects and Challenges for Pakistan
}

Aqsa Ijaz, Faculty of Shariah and Law, International Islamic University, Islamabad, Pakistan *Attia Madni, Faculty of Shariah and Law, International Islamic University, Islamabad, Pakistan Naureen Akhtar, Faculty of Shariah and Law, International Islamic University, Islamabad, Pakistan

*Corresponding author's email: atia.madni@iiu.edu.pk

\begin{tabular}{l}
\hline ARTICLE DETAILS \\
\hline History \\
Revised format: May 2021 \\
Available Online: Jun 2021
\end{tabular}

Keywords

Diversion, Rehabilitation

centers, Observational

homes, Juvenile

delinquency, JJSA( Juvenile

Justice System Act, 2018)

\section{JEL Classification}

H2O, H26

\section{ABSTRACT}

Purpose: This paper develops a framework for analyzing the practical implementation of Juvenile Justice System Act 2018, and bottlenecks which are being faced by the juvenile during the process of trial before the court of law. Few areas need to be examined while determining the practical implementation of this act, as its procedural requirements have not been yet followed in the field. This paper aims to identify those obstructions which are necessary to be dealt with iron hand in order to ensure the full implementation of the act.

Design: Qualitative content analysis method has been used to analyze the various factors, which are responsible for the failure to implement the said act.

Findings: Findings on the topic suggest that even at the stage of registration of first information report, the age of juvenile is neglected and loopholes continues till the conclusion of trial. The crux is that in order to avoid the exploitation of juvenile offender during trial, the Provincial and Federal Governments should play their role to ensure that procedural requirements are met as envisaged by the said act.

Implications: The practical and firm implementation of Juvenile Justice System Act 2018, competent authorities and requisite institutions should realize their role.

(C) 2021 The authors, under a Creative Commons Attribution-Non Commercial 4.0

Recommended citation: Ejaz A, Madni, A. and Akhtar, N. (2021). Implementation of Juvenile Justice System Act, 2018, Prospects and Challenges for Pakistan, Review of Politics and Public Policy in Emerging Economies, 3(1), 79-85.

\section{Introduction}

In order to build the topic in its true sense, it is necessarily to understand the background of the enactment of Juvenile Justice System Act 2018. So in order to elaborate that which law has been prevailed before this act. And the relevant circumstances that convinced the legislature to enact the new one. Firstly, Criminal Procedure Code 1860, has provided the specific provision (section 
497) regarding the bail of juvenile offender (Pakistan Penal Code, 1860). In which it has been provided that court will look into the age of minor offender while granting the bail. Secondly, under Article 25 of the constitution (Constitution of Pakistan 1973), it has been given that state should protect the juvenile whether he is victim or offender. Other related laws which dealt with the juvenile delinquency are Reformatory Schools Act 1897, The Punjab Borstal Act 1926, The Sindh Children Act 1955 and The Probation of Offenders Ordinance 1960. Then Juvenile Justice System Ordinance 2000 was promulgated (Ali khan, 2018). And all the proceedings related to juvenile including bail and probation were dealt under that law. Afterwards, the honorable Lahore High Court had observed in one of its judgment (PLD 2005 page 16) that Ordinance 2000, does not deal with all requirements of juvenile. And therefore, it had directed the legislature to enact the new law. And now this law is dealing with the trial of juvenile offender altogether. As it is the new law, therefore its interpretation is under consideration and practical measures are still lacking, as far as the field is concerned. Courts of the law are delivering judgment keeping in view the new law, but there are still bottlenecks, which are needed to be overcome. Therefore, when special law is enacted, all other laws will not be prevailed. But Juvenile Justice System Act, 2018 has given protection to the Criminal Procedure Code 1860, as no separate procedure has been provided in the Juvenile Act, except the few provisions. It means the basic procedural requirements remain the same (Ali Khan, 2018). In a nut shell, we can say that Juvenile justice System Act 2018, has provided a far better system to deal with the juvenile offenders and it will be implemented in its true sense, then rehabilitation and social integration of the juveniles would be done in a much better way.

Under the said Act, child means a person who has not attained the age of 18 years. JJS Act 2018 has categorized the criminal offences into distinct categories (KLR Publications, 2019). First of all, Minor offences, for which the maximum punishment provided under the Pakistan Penal Code, 1860 is imprisonment for up to three years with or without fine. Meaning thereby, a juvenile will be granted bail in minor offences by juvenile court, either with or without surety bonds. Secondly, there are Major offences, meaning thereby an offence for which maximum punishment provided under the Pakistan Penal Code1860 is imprisonment for more than three years and may extend to seven years with or without fine. Bail shall also be granted in major offences with or without surety bonds by juvenile court. Third category is of the Heinous offences (KLR Publications, 2019) it denotes to the type of offence which are so gruesome and harmful as to threat to public morality and peace, for which punishment provided under the Pakistan Penal Code 1860 is death or imprisonment for life or imprisonment for more than seven years with or without fine. A juvenile of less than sixteen years of age is entitled to bail in heinous offences, but a bail is on discretion of court if juvenile is more than sixteen years of age. There is provision of legal assistance to every juvenile. Accordingly, every juvenile or child victim of an offence shall have the right of legal assistance at the expense of the State. It is mandatory to inform him about his right of legal assistance within 24 hours of taking him into custody (KLR Publications).

Furthermore, there is provision of observation homes. Meaning thereby that juvenile is to be in observation homes after being arrested being apprehended by police. The same provision shall be invoked after obtaining remand of the juvenile. There should also be Juvenile rehabilitation centers, for the purpose of keeping the juveniles there, instead of in jail. A juvenile who has been convicted, shall be kept in the said premises till the completion of period of imprisonment or until he attains the age of 18 years. They are constituted for the purpose of providing vocational training to juveniles (KLR Publications, 2019). Further, JJS Act 2018 has provided a mechanism to determine the true age of offender by the police through ossification test. Medical and birth certificates will be also given weight-age. There is another provision that is Diversion. It does not require to resort to judicial proceedings in order to determine the responsibility of juvenile. The social, cultural, economic, psychological and educational background, of the juvenile will be 
looked upon. The mater can be referred to the Juvenile Justice Committee, either on behalf of victim or juvenile for disposal through diversion. Diversion can only be resorted to if the age of the juvenile is not more than 16 years. Under the process of diversion, sentence of community service may also be included. Oral or written apology may also be demanded. The time limit to decide the case is one month by the juvenile justice committee. It may also issue directions to the rehabilitation Centre, to comply with provisions of providing social welfare and social integration to the juvenile. The juvenile justice Committee shall comprise of the Judicial Magistrate, who is invested with the powers under section 30 of Criminal Procedure Code, including public prosecutor and social welfare. Furthermore, there should be Separate challan and trial of juvenile offenders. As it is not allowed by law to charge and try the juvenile together with an adult person. The personal appearance of juvenile may be dispensed with if the circumstances requires the joint trial (KLR Publications). The identity of juvenile is required to be kept secret unless permission of court is seek for special purpose. The act also entails the penalty for the publisher who acts otherwise. Furthermore, juvenile may be also be released under the supervision of probation officer (KLR Publications, 2019). And he is under duty to submit his report, whenever required by the court. There is also provision regarding disqualification. Removal of disqualification attached with conviction. A juvenile offender convicted under the provisions of JJS Act 2018 shall not be disqualified for the purpose of future endeavors. After thoroughly examining the provisions of JJSA and background, its practical implementation will be analyzed and related obstacles will be scrutinized.

\section{Bottlenecks in its Practical Implementation}

Firstly, at the stage of registration of first information report, the police always fails to determine the exact age of offender (Coleridge \& Ghulam Qadri, 2006). They simply put the juvenile under the category of 16 to 18 years of age by his physical appearance, without going for the ossification test, as envisaged by the law. Even, medical test is not being done in this context. Secondly, there exists no separate juvenile courts for the trial of juvenile offenders, except the one established at judicial complex Lahore (Coleridge \& Ghulam Qadri , 2006). Furthermore, session judges are being entrusted with the cases. As they are already over-burden with other lot many tasks. Another loophole is that female juvenile offenders are being investigated by the male officers. Sexual abuse of the juveniles is at the rise. There is also lack of rehabilitation centers at the district levels. And it is clear violation of the provisions of JJSA. There has not been constituted any juvenile justice committee, since the enactment of the act. Bail discrimination also exists. Furthermore, there is a need to enact the new rules of business, as old ones have been abolished after the repeal of old act. These rules need to be re-enacted as per provisions of new law. It is a dismay state of affairs that neither provincial federal government has provided the adequate and sufficient funds to cope up the needs of the new law (Coleridge \& Ghulam Qadri, 2006). However, Pakistan is signatory of the Convention on Rights of Child (CRC), but in field implementation is lacking at very point. Though, the CRC has not fixed the minimum age for criminal liability, but it has been left upon to the states to fix that age limit that is not too low. It is provided in CRC that every state should ensure the correct and feasible measures to protect the child, in every aspect (Happold, 2006). Rome Statute is also being violated, in the sense that it provides the customary international law to protect the best interest of child (Happold, 2006).

Furthermore, In Pakistan, there are laws who are treating the juvenile delinquency but the basic infrastructure doctrine and system is not developed yet. There are institution who are dealing with the said cause but they are very less in number. For example, there are hardly two to three borstal schools in the province of Punjab (Government of Pakistan, 2009). And the rehabilitation centers which are already constituted, are not equipped with the sufficient tools to bring the child back into the society. There condition is very deplorable and the environment is not convincing at all. Up till today, the Borstal institutions are regulated by the jail manuals, and they need to be regulated under Borstal Act, to ensure their credibility (Government of Pakistan, 2009). There has 
not been provided any threshold in a country to keep the record of juvenile offenders. There are no periodical reports available that show the official juvenile offenders data.

\section{Absence of Coherent Policy}

Though the requisite law is present in the form of JJSA but there is no well-organized policy regarding the juvenile justice system, in order to align it with the international standards. It is required so that the management of the relevant authority is to bee guided by its main principles (Sajjid , 2009). The well cogent policy in any system helps the seat bearers to implement the law in an effective way. This requisite policy needs to be in accordance with the international standards. For example, it is has been provided in the CRC that juveniles should be treated equally and that they should not be discriminated on any ground. Violence in any form against the juveniles is prohibited in the said convention (Sajid , 2009).

\section{Other Key Challenges}

The awareness in police regarding the juvenile delinquency is at minimal level. While apprehending the juvenile, they even ignore the statutory provision to determine the age of the offender. They simply make guess of the age by physical appearance and put him under any category of age, which is very fatal for the fair trial of juvenile during the process of trial (Fassidudin, 2010). The practice is prevalant amongst police. Secondly, torture and violence during the apprehension by the police is another dilemma. Juveniles are also subjected to sexual abuse in the hands of police and only the right guidance awareness can nullify this treatment. Therefore, different training programs need to be conducted on juvenile delinquency in order to abreast the police with the latest knowledge and international instruments, on the subject. A separate investigation teams need to be formulated, who only deals with the matters of juvenile delinquency.

Police are further required to adopt the process of diversion and to impose the fine or other such monetary compensation, where minor offence is committed by the child. It has been observed that sometimes in certain cases, police deliberately avoid to determine the age of offender, and so that they may not indulge in the given legal process and requisite procedures. They even do not mention the age of juvenile on the required slip (Fasuddin, 2010). Accused had undergone trial before the court of law, on the basis of school leaving certificate. The burden to prove that he was child and below 18 years of age, rested on the offender, which he had failed to discharge. On conducting medical test, fact came into limelight that he was 20 years of age, and that did not fall under the juvenile's category. The observation which had been made by the session court regarding the age, while dealing with the bail, was not given priority over the said medical report. And the offender was sent to trial before the additional session court (2001 YLR Page 276). Hence, age should be determined at the time of registration of first information report by the police, to avoid any lacuna during the trial.

Furthermore, if one looks into the role of prosecutors in the cases of juveniles, then it also not satisfactory on that front. They lack the basic expertise in order to tackle the various issues related to juvenile. There are no specialized prosecutors in the given field and they are accustomed to treat the juvenile as an adult.

Another important provision in the JJSA is regarding the probation. Unfortunately, judicial officials even fail to understand the probation system, due to lack of adequate awareness. When the probation order is made, the juvenile is normally subjected to the labor, which falls under the category of child labor. And during that period, no formal education is provided to the child, and this practice is detrimental to his rights (Shafiq, 2010). Further, it has been explicitly provided in JJS Act that the government in consultation with the concerned high court shall designate juvenile court for one or more session's divisions within a period of three months from the 
commencement of this Act. And that it shall be notified in the official gazette. But separate juvenile courts are still not established in every district of Pakistan. And this is very alarming situation at hand. It is observed that the trial judges have been inclined to give weight to Saza Slip. Even the factor of determining age at the stage of trial is neglected by the judges ( Warraich, 2020). They tend to ignore this important factor if the juvenile is involved in the commission of heinous offence. The role of Research Reclamation and Probation Department (RPD) is also not anticipatory in this behalf. As it is the focal point of the juvenile justice system. So it needs to adopt the active approach (Shafiq, 2010).

Furthermore, due to the lack of adequate funds and space, juvenile offenders are being kept in the ordinary jail, where hardened criminals are already present. Hence, chances of juvenile to mix up with the adult convicted offenders may also turn them into habitual criminals. All these crucial factors have been contributed towards the failure in the implementation of JJSA 2018, since its very enactment up-till now.I

\section{Absence of Veracious Mechanisms}

The reliable mechanisms marked a great deficiency in the practical implementation of JJSA. The burning question in this scenario is that who would be responsible for the management of technical schools and observation homes for juveniles? These include issues such as who will provide and manage this observation home? What are the basic infrastructure requirements for these kinds of vocational training institutes? Whether these would be attached to some parent department or they would be established at different localities? All these questions need exploration at hand and require a deep concern by the relevant authorities.

\section{Need to Enact New Buisness Rules}

There is an immediate need to enact the new rules of business to tackle the challenges which are being faced in the practical implementation of JJSA, 2018. Only after these necessary enactments, the provision of relevant budget, establishment of adequate rehabilitation centers and other basic facilities could be made possible In this perspective, political commitment is needed from the high ups, otherwise the fate of new act would be the same as of Juvenile Justice System Ordinance, 2000. The new rules besides other factors may give the ray of hope, that JJSA would be implemented in true spirit. In a consequence, the juvenile justice system is rarely beneficial to those for whom it was enacted. As it failed to protect juvenile offenders. They have not been given proper and due course of law to file an appeal even, in case of convictions. In turn, all these loopholes directly violates the main theme of international law related to the juvenile offenders. The matter at hand needs the instant remedy.

All these factors have been contributing towards the hindrances, which occurred only due to the pathetic process, which is being followed during the trial of the juveniles in Pakistan. And it is the burning question after the enactment of new law, that how and when these lacunas would be fulfilled by the appropriate and relevant authorities. These bottlenecks have been contributing harshly towards the failure in the practical implementation of JJSA.

\section{Role of Associated Agencies}

The department of police, probation services, prosecution, courts, and observational institutions are the main touchstones of the juvenile justice system. But juvenile justice policy should need to consider the other important components and associated agencies of the juvenile justice system as well. The Social Welfare Department and Probation Reclamation department, should play their utmost role utilize their services for different vocational program. The Ministry of Human Rights, print and electronic media, Ministry of Law and other agencies related closely with criminal justice should be given due attention and upper hand in policy making. 


\section{Conclusions and Recommendations}

Though a law for the juvenile offenders is present in the form of Juvenile Justice System Act, 2018. But perfect theoretical framework is of no use without practical implementations. It has provided the guidelines but those are not followed in their true spirit. The true imposition of any act in given system cogitate its inspirations towards the accepted international standards worldwide. The dormant role of all the institutions related to juvenile delinquency can be wakeful if proper policy on the subject will be formulated, that will guide all the stakeholders in their requisite role. Some of key needed measures to be adopted in this context are the provision of adequate funds by the relevant authorities, constitution of juvenile courts particularly with purpose of handling matters related to children's criminal liability. There is also need to establish as much borstal schools for the juveniles as per requirement. Reforms need to be brought in the police and law enforcement agencies as well, so that they may be able to handle the said matter with efficiency. Probation officers need to understand their role, in true sense. They need to be aware about the fact that juveniles should not be subjected to child labor under their supervision. They should ensure the provision of formal education to the juveniles during the period of probation. Judicial officials should also play their role by indicating the loopholes in the police investigation, during the process of trial.

It is the need of the hour that Pakistan should take practical steps towards the formulation of cohesive policy on the juvenile justice system. Only well-organized and well-integrated policy on the said issue can influence the stakeholders. Central and provincial governments should play their role by releasing the adequate funds at the local and district level. Only balanced approach between the institutions can save the situation from further deteriorating. All the relevant institutions should cooperate with each other to make this legal system a better one for juvenile offenders, by acting in the best interest of juveniles.

\section{References}

Ahmed U, Murtaza A.(2016). Factors Affecting Juvenile Delinquency in Punjab, Pakistan: A Case Study Conducted at Juvenile Prisons in Punjab Province, Department of Sociology, University of Sargodha, Pakistan Mediterranean Journal of Social Sciences MCSER Publishing, Rome-Italy2016, Vol 7 No 4.

Canter, R.J.(1974). Family Delinquency. Criminology, Hellfire and Journal of Scientific study of Correlates of Male and Female, 1998 20(2):149-167.

Constitution of Pakistan, 1973.

Elliott, D.S., and Menard, S.(2011). Delinquent friends and delinquent behaviour: Temporal and developmental patterns. In Delinquency and Crime: Current Theories, edited by J.D. Hawkins. New York, NY: Cambridge University Press, 28-67.

Fasihuddin,.(2010). Development of juvenile justice system in Pakistan, Ausaid Ala Fellowships Program Bridging the Research-Policy Divide National Centre for Epidemiology and Population Health (NCEPH) The Australian National University (ANU) Canberra, Australia, development of juvenile justice system in Pakistan.

Government of Pakistan. (2009). Third and fourth periodic reports of State parties

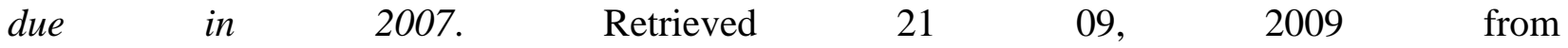
http://www2.ohchr.org/english/bodies/crc/docs/CRC.C.PAK.Q.3-4.pdf

Happold M.(2006). The age of criminal liability in international criminal, Université du Luxembourg; University du Luxembourg - Faculty of Law, Economics and Finance,.

Hassan, S.(2010). Parent and teacher based epidemiological survey of psychiatric morbidity amongst school children in Karachi, Pakistan. PhD thesis. Department of Health Sciences, University of Leicester.

Junger-Tas, J.Trends in International Juvenile Justice: What Conclusions can be Drawn. In J. Junger-Tas, \& S. H. Decker (Eds.), International Handbook of Juvenile Justice. Dordrecht: Springer. 
Juvenile Justice System Act, 2018: http://senate.gov.pk/en/acts.php.

Juvenile. (2009). Retrieved 09 07, 2009, from Merriam-Webster Online Dictionary: http://www.merriam-webster.com/dictionary/juvenile.

Malik Ali W, The Juvenile Justice System Act of 2018, https://thecsspoint.com/the-juvenilejustice-system-act-of-2018-by-wajahat-ali-malik/.

Mohammad Akhtar Vs Muhammad Riaz case citation 2001 YLR Page 276

Pakistan Penal Code 1860, KLR Publications (bare act).

Pakistan: Denial of Basic Rights for Child Prisoners. (2003). Retrieved 09 03, 2009 , f r o m A

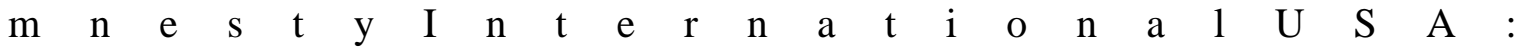
http://www.amnestyusa.org/document.php?id=ENGASA33021005/=e.

Sajjid A.(2009). Juvenile justice policy in pakistan,Gaps Identification and Role of Key Stakeholders, Pakistan Journal of Criminology, Volume 1, No. 3, October , 119 - 138.

Shafiq S.(2010). Juvenile Justice System in Pakistan .http://sja.gos.pk/assets/presentations/Juvenile\%20Justice\%20System.pdf.

Shehryar Warraich, Justice for Juveniles, Political Economy The News July 12, 2020.https://www.thenews.com.pk/tns/detail/685289-justice-for-juveniles

Talpur, F., P. A. \& P.(2011). Shah, Examining the causes of juvenile delinquency in Pakistan. Annual Research journal,Vol. 4.

United Nations, Standard Minimum Rules for The Administraion of Juveile Justice (The Beijing Rules) 1985.

UNODC.. Cross-Cutting Issues: JuvenileJustice: Criminal Jusice Assessment Toolkit. New York: Retrieved 17 06, 2009 from http://www.unodc.org/pdf/criminal_justice/0655616_ebook.pdf

UN Committee on CRC. (2007). General Comment No. 10. United Nations. Retrieved 17 09, 2009 from http://www2.ohchr.org/english/bodies/crc/docs/CRC.C.GC.10.pdf. 